\title{
Influence of Central Venous Oxygen Saturation on In-hospital Mortality of Surgical Patients
}

\author{
João Manoel Silva Junior, TSA ${ }^{1}$, Amanda Maria Ribas Rosa Oliveira 2, Sandra Zucchi de Morais ${ }^{3}$, \\ Luciana Sales de Araújo ${ }^{3}$, Luiz Gustavo F Victoria, TSA ${ }^{4}$, Lauro Yoiti Marubayashi ${ }^{5}$
}

Summary: Silva Junior JM, Oliveira AMRR, Morais SZ, Araújo LS, Victoria LGF, Marubayashi LY - Influence of Central Venous Oxygen Saturation on In-hospital Mortality of Surgical Patients.

Background and objectives: Low central venous oxygen saturation $\left(\mathrm{ScvO}_{2}\right)$ indicates an imbalance between cellular oxygen supply and consumption and, consequently, worse prognosis for critical patients. However, it is not clear what the value of this marker in surgical patients. The objective of the present study was to evaluate whether low perioperative $\mathrm{ScvO}_{2}$ determines a worse prognosis.

Methods: This is a 6-month observational study carried on in a tertiary hospital. Patients who needed to be in the intensive care unit (ICU) postoperatively, with age $\geq 18$ years, who underwent large surgeries, were included. Patients who underwent palliative surgeries and those with severe heart failure were excluded. Levels of $\mathrm{ScvO}_{2}$ were measured before the surgery, during the procedure, and after the surgery in the ICU.

Results: Sixty-six patients were included in this study, but $25.8 \%$ of them did not survive. Mean $\mathrm{ScvO}_{2}$ levels were higher intraoperatively, $84.7 \pm 8.3 \%$, than preoperatively and in the ICU, $74.1 \pm 7.6 \%$ and $76.0 \pm 10.5 \%(p=0.0001)$, respectively. However, only preoperative $\mathrm{SvcO}_{2}$ levels of non-surviving patients were significantly lower than those who survived. By logistic regression, preoperative $\mathrm{ScvO}_{2}, \mathrm{OR}=0.85(95 \% \mathrm{Cl} 0.74-0.98)(p=0.02)$, was an independent factor of in-hospital mortality. Patients with preoperative $\mathrm{ScvO}_{2}<70 \%$ had greater need of intraoperative blood transfusion $(80.0 \%$ versus $37.0 \%, p=0.001)$ and volume replacement, $8,000.0(6,500.0-9,225.0) \mathrm{mL}$ versus $6,000.0(4,500.0-8,500.0) \mathrm{mL}(\mathrm{p}=0.04)$, with greater chances of postoperative complications (75\% versus $45.7 \%, p=0.02)$ and longer time in the ICU, $4.0(20.0-5.0)$ days versus $3.0(1.7-4.0)$ days $(p=0.02)$.

Conclusions: Intraoperative $\mathrm{ScvO}_{2}$ levels are higher than those both in the pre- and postoperative period. However, low preoperative ScvO determines worse prognosis.

Keywords: COMPLICATIONS: mortality; OXYGEN: consumption, blood levels; RISK: factors.

[Rev Bras Anestesiol 2010;60(6): 593-602] @Elsevier Editora Ltda.

\section{INTRODUCTION}

It is estimated that 234 million large surgeries are performed each year ${ }^{1}$. Complications after large surgeries represent causes of morbidity and mortality. High risk surgical patients represent $15 \%$ of all procedures, but more than $80 \%$ of deaths ${ }^{2,3}$.

The data confirms that unfavorable outcomes after high risk surgeries represent a global problem ${ }^{4-6}$. Even in patients who survive hospitalization, complications remain an important determinant of a short survival time ${ }^{6}$. Therefore, it is essential to look for tools to improve the outcome of patients undergoing large surgeries.

Received from the CET/SBA of Hospital do Servidor Público Estadual (HSPE), SP, Brazil.

1. Anesthesiologist, Coordinator of the Surgical Critical Care Unit, Coresponsible for the CET/SBA of HSPE; Physician in Charge of the Scientific Area of the Critical Care Unit of HSPE

2. Critical Care Physician, Intensive Care Unit of HSPE

3. Resident of HSPE

4. Anesthesiologist, Physician in Charge of the Anesthesiology Residency Program of HSPE

5. Anesthesiologist, Director of the Cooperativa Médica de Anestesiologistas de São Paulo of HSPE

Submitted on April 18, 2010.

Approved on June 28, 2010.

Correspondence to:

Dr. João Manoel Silva Júnior

Rua Pedro de Toledo, 1800 - 6andar

Vila Clementino

04039-901 - São Paulo, SP

E-mail:joao.s@globo.com
Several reports indicate that poor outcomes after large surgeries are strongly associated with imbalances in oxygen delivery related to hindered microvascular flow ${ }^{7,8}$. The use of fluids and inotropic drugs increases the oxygen delivery and it can reduce the incidence of complications ${ }^{9,10}$.

Several studies in the literature describe changes in perioperative central $\left(\mathrm{ScvO}_{2}\right)$ and mixed $\left(\mathrm{SvO}_{2}\right)$ oxygen saturation $^{11}$ and in patients with severe sepsis ${ }^{12}$, which have led to the use of venous saturation as a therapeutic target in surgical patients. However, the complex physiology of venous oxygen saturation in surgical patients is poorly understood. Detailed understanding of those principles is essential for the safety and effective application of $\mathrm{ScvO}_{2}$ in clinical practice. Recently, two studies ${ }^{13,14}$ with surgical patients demonstrated the impact of low intraoperative venous saturation on complications, but not on mortality.

The objective of this study was to evaluate intraoperative $\mathrm{ScvO}_{2}$ as risk factor for complications and death in surgical patients admitted to the ICU.

\section{METHODS}

After approval by the Ethics and Research Commission, this study was carried on in a tertiary hospital. This is an observational study whose inclusion criteria were patients ages $\geq 18$ years who underwent surgeries, needed intraoperative central venous catheter, and required postoperative admission to the ICU. 
Patients who underwent palliative surgeries, with low life expectancy, liver failure (Child B or C), functional class IV heart failure or ejection fraction lower than $30 \%$ on echocardiogram, and those who did not agree to participate were excluded.

The primary outcome of this study was hospital mortality according to venous saturation. Thus, every patient was followed-up until hospital discharge. The secondary outcome was the evaluation of intraoperative complications, such as the intraoperative need of blood transfusion, volume replacement, and vasopressors and, postoperatively, the presence of organ dysfunction, shock (need of vasoactive drugs for over one hour despite volume resuscitation), worse pulmonary exchange $\left(\mathrm{PaO}_{2} / \mathrm{FiO}_{2}\right.$ ratio $\left.<200\right)$, renal failure (increase of $50 \%$ in creatinine or urine output lower than $400 \mathrm{~mL}$ in 24 hours), mental confusion (change in behavior, forgetfulness, or psychomotor agitation), and platelet dysfunction (fall of $30 \%$ from baseline levels) up to 24 hours postoperatively. Besides, factors such as infection during the stay in the ICU, length of stay in the ICU, and length of hospitalization were also evaluated.

Initially, patients were divided into two groups: survivors (Group 1) and non-survivors (Group 2). Considering prior studies with $\mathrm{ScvO}_{2}$, the percentage of $70 \%$ was adopted as a cutting point to evaluate intra- and postoperative complications.

Intraoperative treatment was determined by the surgical team. Postoperatively, the goal of the intensive care physician was to improve perfusion parameters and he had no knowledge which group the patient belonged to.

At the time of inclusion the scores of the Multiple-Organ Dysfunction Syndrome (MODS) ${ }^{15}$, Acute Physiology and Chronic Health Evaluation (APACHE II) ${ }^{16}$, and Physiologic and Operative Severity Score for the enUmeration of Mortality and morbidity (POSSUM) ${ }^{17}$ were also evaluated using the worse values of the variables of those scores. Besides, before beginning the surgery, after anesthetic induction, at 3 hours of the procedure, upon admission to the ICU, and after 6 postoperative hours arterial and venous blood gases were collected. The central venous catheter was placed at the right atrial outlet, which was confirmed by a chest X-ray.

Initially, demographic, clinical, and physiologic characteristics of the patients are described. For the description of categorical variables, the frequencies were calculated. Quantitative variables were described by using central tendency and dispersion measurements.

The choice of the statistical method used in the evaluation of each variable was based on its distribution pattern. Categorical variables were analyzed by the Chi-square test, and continuous variables by the mean with the Student $t$ test, for normal distribution, and continuous variables with irregular distribution were analyzed by the Mann-Whitney test. Values of $p<0.05$ (bicaudal) were considered significant. The SPSS 13.0 was used in the analysis of those calculations. Initially, patients in Group 1 were compared to those in Group 2. Afterwards, secondary outcomes were compared starting at a value of $\mathrm{ScvO}_{2}$ equal to $70 \%$, according to prior studies in the literature ${ }^{12,10}$.

Logistic analysis through stepwise analysis was also done to identify independent risk factors and to control confounding effects (mutually adjusted variables). Variables that presented significant probability ( $p$ value) lower than 0.05 in the uni- variate analysis were considered candidates for the multiple regression model.

\section{RESULTS}

From January 1, 2009 to July 1, 2009, 66 patients -37 males and 29 females - with a mean age of 65.6 years were included in this study. Elective surgeries predominated; they were: gastrointestinal $(78.8 \%)$, vascular $(7.6 \%)$, thoracic $(4.5 \%)$, orthopedic $(3.0 \%)$, neurologic $(3.0 \%)$, gynecologic $(1.5 \%)$, and urologic (1.5\%) (Table I).

At the time of surgery, $40 \%$ of the patients received blood transfusions, $32.5 \%$ vasoactive drugs, and an incidence of $54.5 \%$ of postoperative complications was observed, of which shock was the most prevalent $(45.5 \%)$, followed by renal failure (19.7\%), platelet dysfunction (19.7\%), infection (6.7\%), worse oxygenation (10.6\%), and confusion (7.6\%) (Table II).

Mean $\mathrm{ScvO}_{2}$ values of all patients were higher intraoperatively $(84.7 \pm 8.3 \%)$ than preoperatively and in the ICU $(74.1$ $\pm 7.6 \%$ and $76.0 \pm 8.3 \%$ [ $p=0.0001]$, respectively). However, when survivors and non-survivors were compared, only preoperative levels of $\mathrm{ScvO}_{2}$ of non-survivors were significantly lower than those of survivors (Figures 1 and 2).

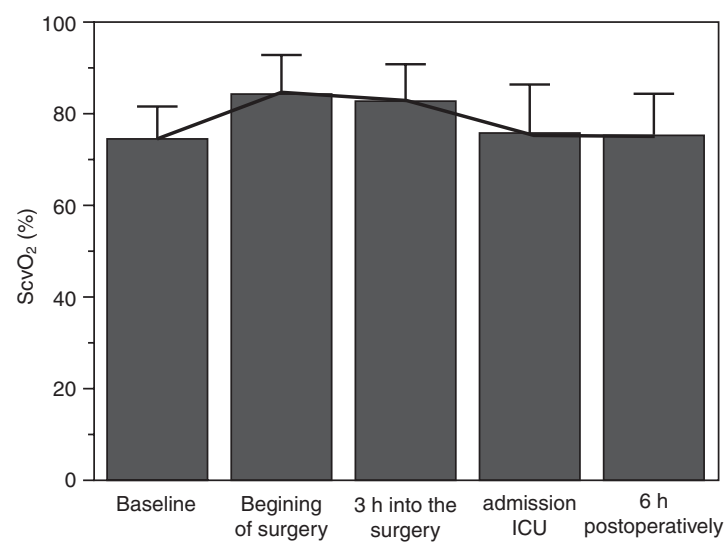

Bars represent means with standard deviation.

Figure 1 - Mean Postoperative $\mathrm{ScvO}_{2}$ Levels.

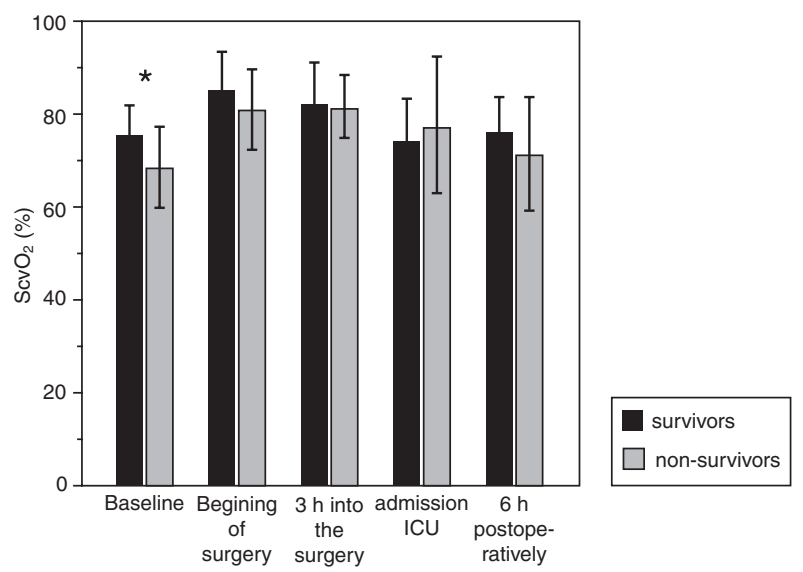

Mean levels of $\mathrm{ScvO}_{2}$ and comparison among survivors and non-survivors, ${ }^{*} \mathrm{p}=0.001$.

Figure 2 - Comparison of $\mathrm{ScvO}_{2}$ in Survivors and Non-survivors. 
In-hospital mortality was $25.8 \%$ (17 patients). Thus, when the groups of survivors and non-survivors were compared by univariate analysis, only 6 variables, among them preoperative $\mathrm{ScvO}_{2}$, APACHE II, MODS, POSSUM, duration of the surgery, and intraoperative need of vasopressors, demonstrated association with hospital mortality (Table I).

However, when variables associated to mortality in univariate analysis were analyzed by logistic regression, only preoperative $\mathrm{ScvO}_{2}, \mathrm{OR}=0.85(95 \% \mathrm{Cl} 0.74-0.98)(\mathrm{p}=0.02)$, and the intraoperative need of vasopressors, OR $=6.77(95 \% \mathrm{Cl}$
1.46-31.30) $(p=0.01)$, were independent factors of in-hospital mortality.

Considering that mean $\mathrm{ScvO}_{2}$ of non-surviving patients was below $70 \%$, and based in prior studies that indicate worse prognosis in patients with $\mathrm{ScvO}_{2}$ below $70 \%$, we compared the outcomes of patients with preoperative $\mathrm{ScvO}_{2}<70 \%$ and those with $\mathrm{ScvO}_{2} \geq 70 \%$. Patient with $\mathrm{ScvO}_{2}<70 \%$ had greater need of intraoperative blood transfusion and volume replacement, greater chances of postoperative complications, and longer staying in the ICU (Table II).

Table I - Comparison of Surviving and Non-surviving Patients

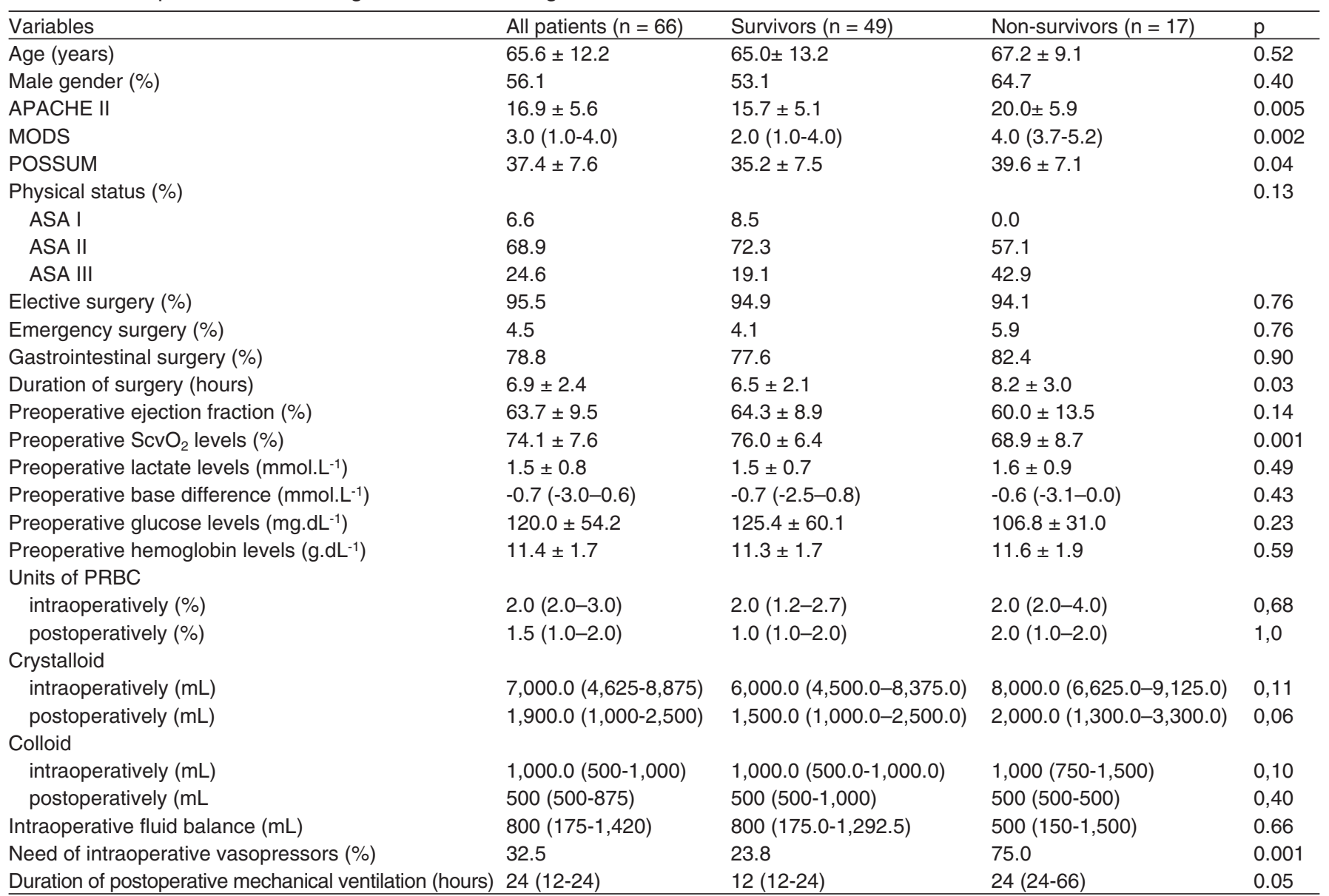

Crystalloid, $0.9 \%$ saline solution and Ringer's lactate; Colloid, hydroxyethyl starch; PRBC - packed-red blood cells; ScvO ${ }_{2}-$ central venous oxygen saturation; vasopressors, catecholaminergic drugs; values in parenthesis represent median and $25 \%-75 \%$ percentile.

Table II - Outcomes

\begin{tabular}{|c|c|c|c|c|c|c|}
\hline Variables & All patients $(n=66)$ & $\mathrm{ScvO}_{2}<70 \%(\mathrm{n}=20)$ & $\mathrm{ScvO}_{2} \geq 70 \%(\mathrm{n}=46)$ & $P$ & OR & $95 \% \mathrm{Cl}$ \\
\hline Preoperative hemoglobin levels (g.dL-1 $)$ & $11.4 \pm 1.7$ & $10.5 \pm 1.6$ & $11.7 \pm 1.6$ & 0.03 & & $0.1-22$ \\
\hline Intraoperative blood transfusion (\%) & $50.0 \%$ & 80.0 & 37.0 & 0.001 & 6.8 & $1.9-23.8$ \\
\hline Need of intraoperative vasopressors (\%) & 32.5 & 40.0 & 33.3 & 0.44 & 1.3 & $04-4.5$ \\
\hline Intraoperative crystalloids (mL) & $7,000.0(4,625-8,875)$ & $8,000.0(6,500.0-9,225.0)$ & $6,000.0(4,500.0-8,500.0)$ & 0.04 & & \\
\hline Intraoperative colloids (mL) & $1,000.0(500-1,000)$ & $1,000.0(625.0-1,000.0)$ & $1,000(500-1,125)$ & 0.96 & & \\
\hline Postoperative complications (\%) & 54.5 & 75.0 & 45.7 & 0.02 & 3,6 & $1.1-11.5$ \\
\hline Duration of ICU stay (days) & $3.0(2.0-4.0)$ & $4.0(2.0-5.0)$ & $3.0(1.7-4.0)$ & 0.02 & & \\
\hline Length of hospitalization (days) & $20.0(12.5-27.5)$ & $20.0(16.0-28.0)$ & $17.0(11.2-2 ., 0)$ & 0.39 & & \\
\hline Duration of postoperative mechanical & $24(12-24)$ & $24(15-24)$ & $12(12-24)$ & 0.08 & & \\
\hline
\end{tabular}

ventilation (hours)

Vasopressors, catecholaminergic drugs; Crystalloid, $0.9 \%$ saline solution and Ringer's lactate; Colloid, hydroxyethyl starch solution; values in parenthesis represent median and $25 \%-75 \%$ percentile. 


\section{DISCUSSION}

The findings of the present study considered that low preoperative $\mathrm{ScvO}_{2}$ in high risk surgeries is associated with inhospital mortality. In multivariate analysis, only preoperative $\mathrm{ScvO}_{2}$ and intraoperative vasopressors represented independent risk factors for in-hospital morality.

Besides, preoperative levels of $\mathrm{ScvO}_{2}$ below $70 \%$ determined worse intra- and postoperative evolution. Currently, few parameters are used in clinical practice to assess tissue hypoxia, such as urinary output, acid-base differences, and plasma lactate levels; however, those parameters show that hypoperfusion is already installed and they can be late parameters to guide the onset of hemodynamic resuscitation ${ }^{18}$.

Notwithstanding, the present study showed that $\mathrm{ScvO}_{2}$ is an early parameter to identify worse evolution in surgical patients. Those results encourage studies to adopt $\mathrm{ScvO}_{2}$ as a therapeutic goal in high risk surgical patients. Based on these data, and in agreement with other studies ${ }^{13}$, preoperative levels of $\mathrm{ScvO}_{2}$ should be over $70 \%$ to $75 \%$ and levels below $70 \%$ should be avoided.

Abnormalities in venous saturation are common during and after large surgeries and they are associated with an increased incidence of postoperative complications ${ }^{19,20}$. Reduced $\mathrm{ScvO}_{2}$ also has prognostic meaning in patients with heart failure, trauma, and sepsis ${ }^{21,22}$. Facing the extensive abnormality rate that affects perioperative venous saturation, those observations are not surprising $11,13,19$.

Thus, the present study demonstrated that intraoperative $\mathrm{ScvO}_{2}$ levels were higher than both pre- and postoperative levels, and that only low preoperative $\mathrm{ScvO}_{2}$ levels were associated with higher mortality rate. Very few data in the literature describes the normal value of venous saturation in healthy patients, such the current study, in which the majority of patients were classified as ASA II and with low APACHE II and POSSUM scores. Although, it is commonly estimate in $70 \%$, the data suggest that it can vary from $70 \%$ to $80 \%$ in healthy individuals $11,23,24$. However, $\mathrm{ScvO}_{2}$ levels can frequently be as low as $65 \%$ in patients hospitalized before elective surgeries ${ }^{25}$.

In addition, the $\mathrm{ScvO}_{2}$ can be reduced as a result of variables that increase oxygen consumption or decrease systemic oxygen delivery. The opposite increases $\mathrm{ScvO}_{2}$ levels ${ }^{26}$. Thus, variables such as pain, stress, and hyperthermia are related to the preoperative period, increasing oxygen consumption. However, the reduction in cardiac output, either by a preoperative hypovolemia or reduction in the levels of hemoglobin, favors a reduction in oxygen delivery ${ }^{11,26}$, which explain the importance of this variable in the preoperative period, especially in patients who will undergo gastrointestinal surgeries since they need colon preparation that causes great preoperative spoliation and hypovolemia ${ }^{27}$, corroborating the present study because the majority of the patients underwent gastrointestinal surgeries.

On the other hand, during the surgery, hypothermia, anesthesia, and increase in the fraction of inspired oxygen increase $\mathrm{SvcO}_{2}$ ${ }^{27}$ levels, making this parameter poorly reliable and confounding as a prognostic marker. Postoperatively, patients were reanima- ted in the intraoperative period, leading to a systemic rearrangement, which makes it difficult to observe low $\mathrm{SvcO}_{2}$ levels.

Two studies with non-cardiac surgery patients evaluated the role of $\mathrm{SvcO}_{2}$ with supplementary findings. In the first observational study ${ }^{13}$ with 117 patients, lower early postoperative levels of $\mathrm{SvCO}_{2}$ associated with subsequent complications was the best independent lower cutting point of $\mathrm{SvCO}_{2}$, of $64.4 \%$. A considerable reduction in $\mathrm{SvcO}_{2}$ within the first postoperative hour, possibly as a consequence of the increase oxygen consumption after the end of general anesthesia in patients who were not properly reanimated in the intraoperative period, was observed. In another observational multicenter study ${ }^{14}$ with 60 patients, mean $\mathrm{SvcO}_{2}$ levels were reduced in several perioperative moments in patients who developed complications. The best cutting point in this study for mean $\mathrm{SvcO}_{2}$ levels was $73 \%$.

Those investigations provide strong evidence to support the role of $\mathrm{SvCO}_{2}$ as a therapeutic goal. However, those findings do not reveal how venous saturation should be used as a therapeutic goal and they did not achieve enough statistical power for a reduction of mortality.

Thus, emphasizing an early risk factor for low oxygen delivery evaluated by perioperative levels of $\mathrm{SvcO}_{2}$ is important, since changes in clinical management can be executed to avoid unfavorable evolution in this population. Several clinical studies have documented that early aggressive resuscitation with defined protocols improves patient outcomes ${ }^{29,30}$. Those studies adopted therapeutic strategies to increase cardiac function and maintain organ perfusion, resulting in a reduction in the length of stay in the ICU, faster recovery of gastrointestinal function, and reduction of mortality in high risk surgical patients ${ }^{31}$. Thus, low $\mathrm{SvcO}_{2}$ could help to identify those patients who need intraoperative optimization, and some specific pre- or intraoperative measures to guarantee an increase in blood flow could benefit them postoperatively and improve their prognosis.

Interestingly, arterial lactate did not show the same preoperative performance when compare to $\mathrm{SvcO}_{2}$ levels. Serum lactate has been classically accepted as an indicator of anaerobic metabolisms and tissue hypoxia, but it should be emphasized that, in normal conditions, the liver is capable of increasing lactate metabolism so, in situations in which hypoxia and anaerobic metabolism are present, a delay of a few hours is observed between the onset of the phenomena and detection of elevated concentrations of lactate in the blood, justifying the fact that lactate might not be such an early predictive factor as the $\mathrm{SvcO}_{2}{ }^{32}$.

However, one should consider that in clinical practice it might not be convenient to measure $\mathrm{SvcO}_{2}$ intermittently by collecting blood samples, since certain mistakes can occur as a result of a contaminated sample, delay in measurements, and sample collected from an inappropriate site ${ }^{33}$. Besides, it is important to notice that the present study focused on a small population, and larger studies are necessary to better evaluate whether those results are applicable.

Patients undergoing large surgeries with low preoperative $\mathrm{SvcO}_{2}$ levels evolved with worse prognosis in the intra- and postoperative periods. Thus, this marker is important to stratify the risk and suggest a therapeutic routine to be adopted preoperatively. 


\section{REFERÊNCIAS / REFERENCES}

01. Weiser TG, Regenbogen SE, Thompson KD et al. - An estimation of the global volume of surgery: a modelling strategy based on available data. Lancet, 2008;372:139-144.

02. Pearse RM, Harrison DA, James $P$ et al. - Identification and characterisation of the high-risk surgical population in the United Kingdom. Crit Care, 2006;10:R81.

03. Jhanji S, Thomas B, Ely A et al. - Mortality and utilisation of critical care resources amongst high-risk surgical patients in a large NHS trust. Anaesthesia, 2008;63:695-700.

04. Haynes AB, Weiser TG, Berry WR et al. - A surgical safety checklist to reduce morbidity and mortality in a global population. $\mathrm{N}$ Engl $\mathrm{J} \mathrm{Med,}$ 2009;360:491-499.

05. Juul AB, Wetterslev J, Gluud C et al. - Effect of perioperative beta blockade in patients with diabetes undergoing major non-cardiac surgery: randomised placebo controlled, blinded multicentre trial. BMJ, 2006;332:1482.

06. Khuri SF, Henderson WG, DePalma RG et al. - Determinants of longterm survival after major surgery and the adverse effect of postoperative complications. Ann Surg, 2005;242:326-343.

07. Shoemaker WC, Montgomery ES, Kaplan E et al. - Physiologic patterns in surviving and nonsurviving shock patients. Use of sequential cardiorespiratory variables in defining criteria for therapeutic goals and early warning of death. Arch Surg, 1973;106:630-636.

08. Jhanji S, Lee C, Watson D et al. - Microvascular flow and tissue oxygenation after major abdominal surgery: association with post-operative complications. Intensive Care Med, 2009;35:671-677.

09. Pearse RM, Belsey JD, Cole JN et al. - Effect of dopexamine infusion on mortality following major surgery: individual patient data meta-regression analysis of published clinical trials. Crit Care Med, 2008;36:1323-1329.

10. Pearse R, Dawson D, Fawcett $\mathrm{J}$ et al. - Early goal-directed therapy after major surgery reduces complications and duration of hospital stay. A randomised, controlled trial [ISRCTN38797445]. Crit Care, 2005;9:R687-693.

11. Silva Jr JM, Toledo DO, Magalhaes DD et al. - Influence of tissue perfusion on the outcome of surgical patients who need blood transfusion. J Crit Care, 2009;24:426-434.

12. Rivers E, Nguyen B, Havstad S et al. - Early goal-directed therapy in the treatment of severe sepsis and septic shock. N Engl $\mathrm{J}$ Med, 2001;345:1368-1377.

13. Pearse $R$, Dawson D, Fawcett $J$ et al. - Changes in central venous saturation after major surgery, and association with outcome. Crit Care, 2005;9:R694-699.

14. Mayr VD, Dunser MW, Greil V et al. - Causes of death and determinants of outcome in critically ill patients. Crit Care, 2006;10:R154.

15. Marshall JC, Cook DJ, Christou NV et al. - Multiple organ dysfunction score: a reliable descriptor of a complex clinical outcome. Crit Care Med, 1995;23:1638-1652.

16. Knaus WA, Draper EA, Wagner DP et al. - APACHE II: a severity of disease classification system. Crit Care Med, 1985;13:818-829.

17. Prytherch DR, Whiteley MS, Higgins B et al. - POSSUM and Portsmouth POSSUM for predicting mortality. Physiological and Operative Severity Score for the enumeration of Mortality and morbidity. $\mathrm{Br} \mathrm{J}$ Surg, 1998;85:1217-1220. 
18. Rezende E, Silva Jr JM, Isola AM et al. - Epidemiology of severe sepsis in the emergency department and difficulties in the initial assistance. Clinics (Sao Paulo), 2008;63:457-464.

19. Poeze M, Ramsay G, Greve JW et al. - Prediction of postoperative cardiac surgical morbidity and organ failure within 4 hours of intensive care unit admission using esophageal Doppler ultrasonography. Crit Care Med, 1999;27:1288-1294.

20. Polonen P, Hippelainen M, Takala R et al. - Relationship between intra- and postoperative oxygen transport and prolonged intensive care after cardiac surgery: a prospective study. Acta Anaesthesiol Scand, 1997;41:810-817.

21. Ander DS, Jaggi M, Rivers E et al. - Undetected cardiogenic shock in patients with congestive heart failure presenting to the emergency department. Am J Cardiol, 1998;82:888-891.

22. Moomey Jr CB, Melton SM, Croce MA et al. - Prognostic value of blood lactate, base deficit, and oxygen-derived variables in an LD50 model of penetrating trauma. Crit Care Med, 1999;27:154-161.

23. Harms MP, van Lieshout JJ, Jenstrup M et al. - Postural effects on cardiac output and mixed venous oxygen saturation in humans. Exp Physiol, 2003;88:611-616.

24. Madsen $P$, Iversen $H$, Secher $\mathbf{N H}$ - Central venous oxygen saturation during hypovolaemic shock in humans. Scand J Clin Lab Invest, 1993;53:67-72.

25. Jenstrup M, Ejlersen E, Mogensen T et al. - A maximal central venous oxygen saturation (SvO2max) for the surgical patient. Acta Anaesthesiol Scand 1995;(Suppl 107):29-32.

26. Rivers EP, Ander DS, Powell D - Central venous oxygen saturation monitoring in the critically ill patient. Curr Opin Crit Care, 2001;7:204211.]

27. Shepherd SJ, Pearse RM - Role of central and mixed venous oxygen saturation measurement in perioperative care. Anesthesiology, 2009;111:649-656.

28. van Beest PA, Hofstra JJ, Schultz MJ et al. - The incidence of low venous oxygen saturation on admission to the intensive care unit: a multi-center observational study in The Netherlands. Crit Care, 2008;12:R33.

29. Fenwick E, Wilson J, Sculpher M et al. - Pre-operative optimisation employing dopexamine or adrenaline for patients undergoing major elective surgery: a cost-effectiveness analysis. Intensive Care Med, 2002;28:599-608.

30. Mythen MG, Webb AR - Perioperative plasma volume expansion reduces the incidence of gut mucosal hypoperfusion during cardiac surgery. Arch Surg, 1995;130: 423-429.

31. Kern JW, Shoemaker WC - Meta-analysis of hemodynamic optimization in high-risk patients. Crit Care Med, 2002;30:1686-1692.

32. Nguyen HB, Rivers EP, Knoblich BP et al. - Early lactate clearance is associated with improved outcome in severe sepsis and septic shock. Crit Care Med, 2004;32:1637-1642.

33. Edwards JD, Mayall RM - Importance of the sampling site for measurement of mixed venous oxygen saturation in shock. Crit Care Med, 1998;26:1356-1360.

Resumen: Silva Junior JM, Oliveira AMRR, Morais SZ, Araújo LS, Victoria LGF, Marubayashi LY - Influencia de la Saturación Venosa Central de Oxígeno en la Mortalidad Hospitalaria de Pacientes Quirúrgicos.

Justificativa y objetivos: La saturación venosa central de oxígeno $\left(\mathrm{SvcO}_{2}\right)$ baja indica un desequilibrio entre la oferta y el consumo de oxígeno celular y como consecuencia, un peor pronóstico para los pacientes graves. Sin embargo, todavía no está claro cuál es el valor de ese marcador en pacientes quirúrgicos. El objetivo de este estudio fue evaluar si la $\mathrm{SvcO}_{2}$ baja en el perioperatorio determina un peor pronóstico.

Método: Estudio observacional durante 6 meses, realizado en un tercer hospital. Fueron incluidos pacientes que necesitasen postoperatorio en cuidados intensivos (UCI), con edad $\geq 18$ años, sometidos a cirugías de gran porte. Los pacientes con cirugías paliativas y pacientes con insuficiencia cardíaca grave quedaron fuera del estudio. Los valores de $\mathrm{SvcO}_{2}$ se midieron antes de la cirugía, durante el procedimiento y después de la operación en la UCI.

Resultados: Se incluyeron 66 pacientes de los cuales un 25,8\% no sobrevivieron. Los valores promedios de SvcO2 de los pacientes fueron mayores en el intraoperatorio, 84,7 $\pm 8,3 \%$, que en el preoperatorio y $\mathrm{UCl}$, respectivamente $74,1 \pm 7,6 \%$ y $76,0 \pm 10,5 \%$ $(p=0,0001)$. Sin embargo, solamente los valores de $\mathrm{SvcO}_{2}$ en el preoperatorio de los pacientes no sobrevivientes fueron significativamente más bajos que los sobrevivientes. La regresión logística SvcO2 preoperatoria, OR = 0,85 (IC 95\% 0,74-0,98) $(p=0,02)$, fue un factor independiente de mortalidad hospitalaria. Los pacientes con $\mathrm{SvcO}_{2}<70 \%$ en el preoperatorio, presentaron una mayor necesidad de transfusión sanguínea $(80,0 \%$ versus $37,0 \% p=0,001)$ y reposición volémica en el intraoperatorio 8000,0 $(6500,0$ - 9225,0) 